28 ; from the honorary secretary, Mrs. Gerald Haythornthwaite, Endcliffe Vale House, Sheffield 10; 1952), after expressing disappointment that the Government's nominees on the Joint Board for the Peak District National Park should include so few with knowledge and experience of rural preservation in the region, stresses the major threat to the Peak constituted by the unlimited demands of the limestone industries to encroach upon the National Park. The Joint Board has adopted the policy that, while quarrying in the Park cannot be excluded, demands should receive the closest scrutiny; but the Joint Committee for the Peak District National Park considers that, in view of proposals to demolish Eldon Hill and to extend the Tunstead Quarries eastward so as to destroy Meadow, Wormhill and ultimately the exquisite series of dales from Peak Forest to Millersdale, the time has come to make a stand for the very existence of the Park and of the Pealk. Open-cast coal-mining still constitutes a threat at Wentworth Woodhouse and in the Cordwell valley, and East Derbyshire continues to lose farmlands and woods at a disastrous rate. Action has also been necessary in regard to Sheffield's Green Belt, on which housing proposals threatened encroachment, as does the Sheffield Development Plan, which fails to indicate Green Belt land as such. In conjunction with the Don Valley Amenities Society, steps have been taken to restore the lost beauty of this Valley, and the first hardwood trees of the Wharncliffe State Forest were planted during November 1951. In spite of protests, the Government has approved the use by the War Department as a training-area and mortarrange of 2,700 acres north of Upper Hulme and west of Staffordshire Roaches in one of the wildest parts of the National Park, and this is a serious loss to amenity.

\section{Journal of the Mechanics and Physics of Solids}

THE first number of a new periodical entitled Journal of the Mechanics and Physics of Solids (1, No. 1, pp. 76 ; $90 s$. per vol. (4 Nos. per vol.) ; London : Pergamon Press, Ltd.) appeared in October under the joint editorship of Dr. R. Hill, of the University of Bristol, and Prof. W. M. Baldwin, jun., of the Case Institute of Technology, United States. The setting-up of this journal, under a distinguished advisory board, marks a further step in the emergence of studies of solid deformation from the general wide background of physics, mathematics, physical chemistry and metallurgy. The process has been detectable for some years, and notably so since 1945 , during which time a vigorous development in solidstate physics, strongly led by physicists in Great Britain and in the United States, has transformed the whole approach to the mechanics of crystals. During these years, the same fundamental problem of elucidating the mechanisms of the deformation of materials and aggregates of various kinds, both metallic and non-metallic, has engaged the attention of research workers in every branch of pure and applied science, and the result of these researches is scattered throughout the literature. The more general that deformation phenomena and theories are discovered to be, the greater does the need become for some common channel of expression. There certainly exists, then, a strong reader-demand for a publication on these lines. As for the writer of research papers, it may be said that the subject with which this new journal is concerned had grown far too large for the journals that already existed. Further, and quite simply, the subject is worthy of a journal of its own. It is clearly not the concern of a publication devoted in the main to fundamental research (and this would appear to be the case to judge from the first issue) to seek any sort of justification for its activities on practical grounds; fundamental research is its own justification. Yet those concerned with the technological development of modern machines (the word is used in its widest sense) know well that the old materials have been exploited to the limit, and far beyond the limit, and that the primary barrier to advance is not the design of successful machines, but their fabrication, for present materials cannot contain them. The importance of the subject is thus in no doubt. Pure and applied science will surely welcome the appearance of this new journal as both timely and valuable.

\section{Fiftieth Volume of the Journal of the Bombay Natural History Society}

ON September 15, 1883, five Scotsmen, one Englishman and two Indians met in Bombay and formed a society for the study of natural history, and this was the beginning of the Bombay Natural History Society. Three years later, though the membership was still small and confined to the residents in or near Bombay, the Society decided on the bold step of starting a journal. At this time there was only one periodical in India-the Journal of the Asiatic Society of Bengal-for the publication of papers on zoology and botany, and these, as a rule, of a strictly scientific character. The aim of the editors of the Bombay Journal has always been to publish not only scientific papers but also articles of a more popular character, and at the same time to encourage members to contribute short notes on any subjects of interest. How successful they have been is shown by the long series of volumes - the fiftieth of which has now been issued $(50$, No. 4 ; from the Society, 114 Apollo Street, Bombay). Many of the volumes run into more than a thousand pages and contain papers of great importance by specialists as well as popular articles such as "A Popular Treatise on the Common Indian Snakes", and the "Beautiful Flowering Trees of India", while the short notes from members have thrown much light on the distribution, etc., of both plants and animals. Though in the main the contributions to the Journal have dealt with the fauna and flora of India, Burma and Ceylon, there have also been a few on countries beyond these boundaries, such as "A Survey of the Fauna of Iraq" started during the First World War. At one time the membership of the Society numbered more than two thousand, and copies of the Journal were in practically every club and mess in India. Since 1947 the membership has decreased, but the standard of the Journal is as high as ever; and for this the editors are to be congratulated.

\section{A Diffusion Reaction Theory of Morphogenesis}

$\mathrm{I}_{\mathrm{N}}$ a recent publication, "The Chemical Basis of Morphogenesis" (Phil. Trans. Roy. Soc., B, 237, 37 ; 1952), Dr. A. M. Turing has advanced the theory that a system of chemical substances, described as morphogens, reacting together and diffusing through a tissue, may account adequately for some of the main phenomena of morphogenesis in plants and animals. The biochemical system in an embryonic tissue, envisaged as being initially quite homogeneous, that is, with a homogeneous distribution on the morphogens, may be 'triggered off' by some random 